University of Nebraska - Lincoln

DigitalCommons@University of Nebraska - Lincoln

\title{
Differences in Distribution of Modified Basins and Ducks Relative to Roadside Transects
}

Jane E. Austin

U.S. Geological Survey, jaustin@usgs.gov

Glenn R. Guntenspergen

U.S. Geological Survey, Glenn_Guntenspergen@usgs.gov

H. Thomas Sklebar

U.S. Geological Survey

T. K. Buhl

U.S. Geological Survey, tbuhl@usgs.gov

Follow this and additional works at: https://digitalcommons.unl.edu/usgsnpwrc

Part of the Other International and Area Studies Commons

Austin, Jane E.; Guntenspergen, Glenn R.; Sklebar, H. Thomas; and Buhl, T. K., "Differences in Distribution of Modified Basins and Ducks Relative to Roadside Transects" (2003). USGS Northern Prairie Wildlife Research Center. 3.

https://digitalcommons.unl.edu/usgsnpwrc/3

This Article is brought to you for free and open access by the US Geological Survey at DigitalCommons@University of Nebraska - Lincoln. It has been accepted for inclusion in USGS Northern Prairie Wildlife Research Center by an authorized administrator of DigitalCommons@University of Nebraska - Lincoln. 


\title{
DIFFERENCES IN DISTRIBUTION OF MODIFIED BASINS AND DUCKS RELATIVE TO ROADSIDE TRANSECTS
}

\author{
Jane E. Austin, Glenn R. Guntenspergen'1, H. Thomas Sklebar, and T. K. Buhl \\ U.S. Geological Survey \\ Northern Prairie Wildlife Research Center \\ Jamestown, North Dakota, USA 58401 \\ E-mail: jane_austin@usgs.gov \\ ${ }^{1}$ U.S. Geological Survey \\ Patuxent Wildlife Research Center \\ University of Minnesota Natural Resources Institute \\ 5013 Millers Trunk Highway \\ Duluth, Minnesota, USA 55811
}

\begin{abstract}
Wetland basins in the Prairie Pothole Region of the U.S. are commonly modified by excavation (e.g., roadside ditches, stock dugouts), partial drainage (ditching), and diking. Differences in the distribution of modified wetlands may affect the predictive accuracy of waterfowl survey data if such wetlands are not distributed randomly in the landscape and if waterfowl are not distributed equally among them. We used data collected on thirty-eight $40-\mathrm{km}^{2}$ plots in North Dakota to examine the distribution of modified basins relative to roadside transects and their use by five species of dabbling ducks in 1995 . The 800-m-wide transects were subdivided into an inner 400-m transect, centered on the road, and the remaining outer transect area. We compared the distribution of modified and natural wetland basins among three sample areas: 1) the inner 400-m-wide roadside transect area, 2) the outer transect area, and 3) the remaining area within the $40-\mathrm{km}^{2}$ plot that was outside of the transects (outer plot). Duck use was compared between the two transect areas. The plots contained 20,582 basins, of which $88.5 \%$ were unmodified, $7.5 \%$ were excavated, $3.7 \%$ were partially drained, and $0.2 \%$ were diked. Nearly all excavated temporary (89\%) and seasonal (90\%) basins occurred in the inner transect area, reflecting the high proportion of basins that would be defined as roadside ditches. Excavated semipermanent basins were more evenly distributed among the outer plot and two transect widths; these basins often were dugouts but also included roadside ditches. Partially drained and diked basins also were fairly evenly distributed among the three sample areas. Semipermanent basins had greater use by mallards (Anas platyrhynchos) and northern pintails (A. acuta) when they were partially drained than when they were excavated or unmodified; pintails also had greater use of partially drained seasonal basins. Use of wetland basins by gadwall (A. strepera), blue-winged teal (A. discors), and northern shovelers (A. clypeata) did not differ among water regimes or modification. We found no evidence to indicate that duck numbers determined from standard 400-m-wide roadside transects were biased relative to the larger landscape. However, pond counts derived from such transects were biased. Correlations of duck numbers to pond counts that exclude ditches or temporary basins would poorly reflect the response of ducks to available water.
\end{abstract}

Key Words: Anas acuta, Anas clypeata, Anas discors, Anas platyrhynchos, Anas strepera, blue-winged teal, gadwall, mallard, modified wetlands, North Dakota, northern shoveler, pintail, Prairie Pothole region, survey methodology

\section{INTRODUCTION}

Wetland basins in the Prairie Pothole Region (PPR) are commonly modified by human activities related to agriculture or roads, such as excavation, partial drainage, and diking (Kantrud et al. 1989). Excavated wetlands most commonly are dugouts, located in isolation or within a natural basin to provide water for livestock, and roadside ditches that resulted from road construc- tion. Partly drained basins are those where the original area of the wetland has been reduced by ditching. Diked wetlands, or impoundments, include wetlands modified to provide water for livestock, control erosion, or flooding (e.g., in small streams or river channels) or to provide water-level management. The frequency and distribution of modified wetlands varies locally and regionally, depending on agricultural development, presence of roads, topography, and soils. 
Modifications to wetlands have increased over the past 20-50 years as agricultural development in the region has intensified (Kantrud et al. 1989). During 1986$1997,51 \%$ of losses to freshwater emergent wetlands nationwide were on agricultural lands (Dahl 2000).

The PPR is a major waterfowl production area in North America and has been the focus of many waterfowl studies. Many studies have examined duck use of wetlands relative to water regime (e.g., temporary, seasonal, or semipermanent hydroperiod), and a number have focused on the use of stock ponds or impoundments by waterfowl (e.g., Lokemoen 1973, Rumble and Flake 1983, Svingen and Anderson 1998). However, we found only one study that compared duck use of modified and unmodified (natural) wetlands (Stewart and Kantrud 1973), and few studies have evaluated the distribution of modified and unmodified wetlands in the landscape. For an area of central North Dakota, Cowardin et al. (1981) reported the percent of wetlands, by water regime, that were characterized as a road ditch, were bisected by a road, were in a drainage, or were tilled, hayed, or in a pasture. In that study, wetland conditions were examined using small $\left(3.22 \mathrm{~km}^{2}\right)$ plots along east-west transects that usually were aligned with roads. Johnson and Higgins (1997) reported wetland numbers and areas by National Wetlands Inventory (NWI) classification types (Cowardin et al. 1979), including modification category (partially drained, diked, excavated, beaver); their report was a complete enumeration of all wetlands mapped by NWI in eastern South Dakota. However, neither study evaluated the distribution of modified wetlands on the landscape or their relative use by waterfowl. The attractiveness or value of a wetland to waterfowl is often degraded by modifications that alter the wetland's hydrology, edge vegetation, water clarity, or aquatic invertebrate foods (Euliss et al. 1999). Nesting cover adjacent to wetlands may be lost if partial drainage allows encroachment of cultivation, diking floods wet meadow or emergent habitat, or roads or other rights-of-way result in periodic haying or burning. Road ditches also may allow movement of fish into previously fish-free wetlands, altering the aquatic invertebrate community (Zimmer et al. 2000).

Differences in the distribution of modified wetlands may affect the predictive accuracy of survey data if such wetlands are not distributed randomly in the landscape, and if waterfowl are not distributed equally among them. Waterfowl populations and associated water conditions often are monitored using roadside belt or strip transects (Dzubin 1969, Serie and Cowardin 1990). For example, strip transects used for annual Waterfowl Breeding Population and Habitat Surveys (WBPHS; U.S. Fish and Wildlife Service and Canadian Wildlife Service 1987) often are positioned along roads in the PPR. All ducks within a 400-m-wide transect $(200 \mathrm{~m}$ on either side of the road or transect center line) are counted, but ponds are counted on only one side of the aircraft and are constrained by type (U.S. Fish and Wildlife Service and Canadian Wildlife Service 1987). The aerial crew does not count temporary wetlands (defined by survey protocol as temporary water, sheet water, or small wet areas in stubble or plowed fields, and wet depressions that have $<15 \mathrm{~cm}$ water depth and can be expected to last $<3$ weeks), roadside or borrow ditches where water is confined entirely to the ditch, and small ditches used for local irrigation. In wet years, numbers of flooded temporary basins and ditches can be high and may contribute to waterfowl response to an area. Thus pond counts from such surveys may not fully reflect the area's water conditions to which ducks may be responding.

Austin et al. (2000) found that wetland basin densities in roadside strip transect samples in North Dakota were greater than densities in hexagonal $40-\mathrm{km}^{2}$ plots; differences were greatest for seasonal and temporary basins. The differences in total basin density disappeared, however, when excavated seasonal and temporary basins were excluded; most of these excavated seasonal and temporary basins were roadside ditches. Further, they found that blue-winged teal and northern shovelers responded more strongly to water closer to the road. These results raised three questions: 1) what is the distribution of modified basins relative to width of roadside transects, 2) what is the distribution of ducks relative to modified and natural basins in the 800-m transect, and 3) what is the significance of these results to waterfowl survey data collected using roadside transects?

We examined these questions using data from an Environmental Monitoring and Assessment Program (EMAP) study (Austin et al. 2001). Data on wetland basins and ducks were collected in 1995 using 800-mwide roadside transects on thirty-eight $40-\mathrm{km}^{2}$ plots systematically located across the PPR of North Dakota. Our objectives were to 1) compare the distribution of excavated, partially drained, and diked/impounded wetland basins in strip transects near the road and in areas away from roads relative to a larger landscape scale; 2) examine the distribution of ducks on modified and natural wetlands, relative to water regime, within the strip transect, and 3) evaluate how these relationships may affect waterfowl survey results.

\section{METHODS}

\section{Basin Data}

For EMAP, North America was divided into a grid of $40-\mathrm{km}^{2}$ hexagonal plots. We selected for study 45 


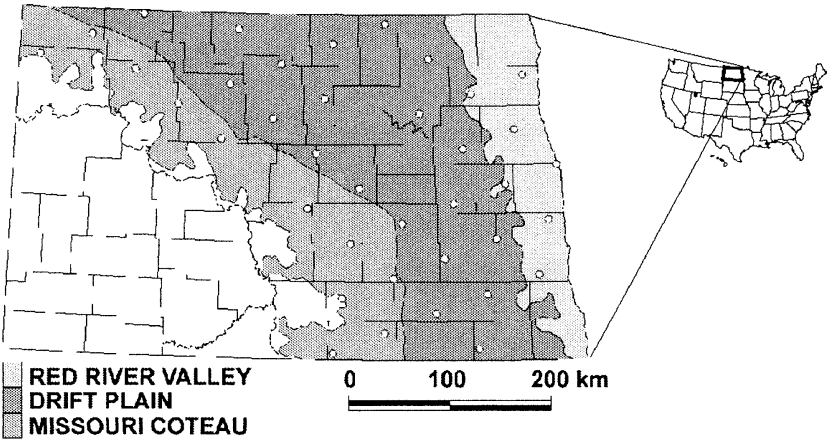

Figure 1. Location of thirty-eight $40-\mathrm{km}^{2}$ plots in North Dakota.

plots in North Dakota east of the Missouri River (Figure 1). Original base maps and geographic information coverages of plots included NWI wetland data collected during 1979 to 1982 . Wetland basins were derived from NWI polygons using ARC-INFO macro language that combined polygons based on deepest water regime (temporary [temporarily flooded each season], seasonal [seasonally flooded], and semipermanent [semipermanently flooded]; Cowardin et al. 1979). These coverages were updated using 1995 aerial photography and data from the U.S. Department of Agriculture's Natural Resources Conservation Service. Coverages were also updated from groundtruthing of 100 wetlands within each plot selected for duck counts (see below). Processing of point and linear basins followed procedures in Cowardin et al. (1995). Area of each basin was determined from NWI vector coverage and rounded to the nearest 0.01 ha. Modifications (excavated, diked, partly drained) to a basin were determined from NWI's classification of those polygons comprising the basin (Cowardin et al. 1979). We considered basin densities from these plots as representative of the larger landscape. Data from the PPR in South Dakota (Johnson and Higgins 1998) indicated that plots of this size would have minimal bias in estimates of basin numbers. Because duck counts were not conducted on seven of the plots due to weather and time constraints, we used data from 38 of the $40-\mathrm{km}^{2}$ plots.

Roadside transects were located along all roads drivable in May 1995 in each study plot. The 800-m roadside transect included all basins within $400 \mathrm{~m}$ on either side of the center of the road. We later subdivided the transect into two sample areas, a center 400-m transect width, which included basins $200 \mathrm{~m}$ on either side of the center of the road, hereafter referred to as the inner transect area, and the remaining outer transect width, referred to as the outer transect area (Figure 2). Basins were included in a transect area if their centroids fell within the transect boundaries. Basins falling outside of the 800-m transect were considered in the outer plot area. Therefore, we considered here three sample areas: the outer plot, outer transect, and inner transect areas.

Austin et al. (2000) reported that densities of seasonal and temporary wetlands were overestimated using either inner or outer transects relative to the entire plot, but they did not specifically examine differences in densities of modified basins among the three sample areas. Therefore, we first examined the differences among the three sample areas. Although we expected inner transect areas to have greater densities of excavated seasonal and temporary basins because of their proximity to the road, we had no expectations for other water-regime-modification combinations. For each sample area within a plot, we calculated basin densities (number per $100 \mathrm{ha}$ ) for each water-regime-modification combination. We then calculated the difference in basin densities in each plot between 1) outer plot and outer transect areas, 2) outer plot and inner transect areas, and 3) outer transect and inner transect areas. Non-overlapping confidence intervals $(\alpha=0.05)$ were interpreted as significantly different.

\section{Duck Population Estimates}

Basins at least partially viewable from the road constituted the sample of wetland basins in each plot for

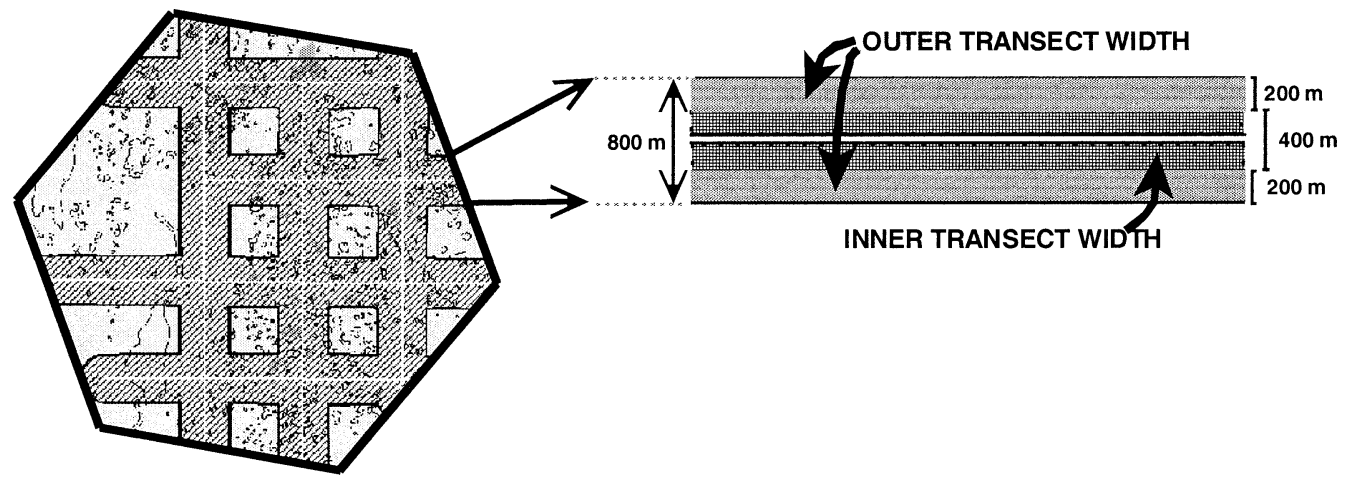

Figure 2. Representation of transect and transect width samples for $40-\mathrm{km}^{2}$ plots. 
duck counts. We used an optimal allocation to select a stratified random subsample of 100 basins from each transect area; we treated the basin water regime (temporary, seasonal, semipermanent) as strata to obtain a sample throughout the range of basin sizes and to avoid over-sampling of small basins (Cowardin et al. 1995). We sampled all basins when there were fewer than 100 basins in a transect. When we were unable to view a basin or found that a basin did not exist, we replaced it with a viewable basin of the same regime located within the 800-m transect area.

We conducted duck counts from vehicles along each road. We did not conduct counts during periods of strong winds or when precipitation reduced visibility, and we avoided counting before 0900 or in late afternoon. We were unable to survey ducks on seven of the 45 plots, so our sample size was reduced to 38 plots. For each basin sampled, we recorded the number of ducks by social groups (Cowardin et al. 1995). Additionally, we estimated the proportion of each basin that could be observed, the proportion that was not obstructed by emergent vegetation, and the areal percent of the basin holding water. We used these estimates to adjust duck counts for the portion of the basin not observed. Our adjustment was based on the assumption that ducks were dispersed equally across the basin and was calculated as follows:

$$
\text { DUCKADJ }=\frac{[\text { BREEDPOP } /(\text { PERCOUNT })]}{[(\text { BASINT/10 }+0.05)]}
$$

where DUCKADJ = adjusted duck count/basin, BREEDPOP $=$ number of breeding duck pairs counted on a basin, PERCOUNT = percent of the basin that could be viewed (i.e., not obscured by topography or structures; to nearest 0.05), and BASINT = viewable proportion of the basin that was not obstructed by emergent vegetation (classified as 0 [0-10\%] to 9 [90$100 \%$ ]; 0.05 added to prevent division by 0 ).

We conducted early (1-15 May) and late (20 May5 June) duck counts during 1995. We used data from early counts to estimate breeding pairs of mallards and pintails, and data from late counts to estimate breeding pairs of blue-winged teal and gadwall (Cowardin et al. 1988). Breeding pairs of northern shovelers were estimated from the count occurring nearest 15 May. We assigned the adjusted duck data for each basin to the inner or outer transect samples using unique basin identifying numbers.

To determine whether modified and natural basins received equal use by ducks, we needed to account for differences in basin characteristics reflective of available water (basin densities and area; Cowardin et al. 1983). We examined $\gamma$ (gamma), a correction factor that accounts for variation in wetland conditions, as our measure of duck response for each wetland type (water regime-modifier combination); $\gamma$ is calculated as the number of ducks counted on an area divided by the number predicted given those wetland conditions. A $\gamma$ greater than 1.0 indicates that more ducks were present than expected relative to expected baseline conditions. We thus interpreted $\gamma$ as a relative measure of use.

We used pair regressions developed for each species by Cowardin et al. (1995) to predict baseline duck numbers given the wetland conditions present for each water regime-modifier combination:

$$
\text { PREDICTED }=\mathrm{A} * \text { AWET }+\mathrm{B} * \sqrt{(\mathrm{AWET})}
$$

where $\mathrm{A}$ and $\mathrm{B}$ are regression coefficients defined by Cowardin et al. (1995) to estimate indicated pairs by species, and AWET is water area of each basin (ha), determined from May 1995 aerial photography (Austin et al. 2001). We weighted DUCKADJ on each basin so that those basins that had a larger portion of their area viewable for ducks, as measured by PERCOUNT and BASINT, received greater weight than those basins that had lower portion viewable. If we set this correction for viewability as follows:

$$
\text { VCORR }=[\text { PERCOUNT } *(\text { BASINT } / 10+0.05)]
$$

then the weighted duck count is:

$$
\text { DUCKADJ }=\text { BREEDPOP/VCORR. }
$$

The weight used in calculating $\gamma$ is:

$$
\text { WEIGHT }=\frac{(\text { VCORR } * N)}{\sum(\text { VCORR })}
$$

where $\mathrm{N}=$ number of basins of each water regime in each transect area. For each species, we calculated ã for each water regime using weighted DUCKADJ for each transect area:

$$
\gamma=\frac{\sum(\text { DUCKADJ } * \text { WEIGHT })}{\sum(\text { PREDICTED })}
$$

Only one plot had diked/impounded wetlands; therefore, we dropped this modifier from the analyses. We compared the weighted $\gamma \mathrm{s}$ among the three modifiers (partially drained, excavated, and unmodified) and water regimes using a two-way factorial in a randomized incomplete block design, with plots as the random blocks and water regime and modifier as the explanatory factors (Littell et al. 1996). The model is an incomplete block design because not all plots had a $\gamma$ for all water-regime-modifier combinations. Analyses were conducted using SAS software PROC MIXED (SAS Institute Inc. 1997). Least squares means estimates of the $\gamma$ values were generated for each water regime-modifier combination along with 
Table 1. Proportion of modified or unmodified wetlands, by water regime, in thirty-eight $40-\mathrm{km}^{2}$ plots in North Dakota.

\begin{tabular}{lrrrrr}
\hline & \multicolumn{4}{c}{ Proportion of Basins Modified } \\
\cline { 3 - 6 } Water Regime & \multicolumn{1}{c}{ No. } & $\begin{array}{c}\text { Unmodi- } \\
\text { fied }\end{array}$ & $\begin{array}{c}\text { Partly } \\
\text { Drained }\end{array}$ & Diked & $\begin{array}{r}\text { Exca- } \\
\text { vated }\end{array}$ \\
\hline All basins & 20,582 & 88.5 & 3.7 & 0.2 & 7.5 \\
Temporary & 8,747 & 93.2 & 5.3 & $>0.1$ & 1.4 \\
Seasonal & 10,401 & 86.5 & 2.6 & 0.1 & 10.8 \\
Semipermanent & 1,434 & 74.3 & 1.5 & 3.0 & 21.1 \\
\hline
\end{tabular}

estimates of standard errors. In addition to the assumption of normality and homoscedasticity, we assumed that the expanded duck count (adjusted for visibility bias) is a reasonable index to duck density (ducks/wet area).

\section{RESULTS}

\section{Basin Characteristics and Distribution}

The 38 plots examined contained 20,582 basins, of which $88.5 \%$ were unmodified, $7.5 \%$ were excavated, $3.7 \%$ were partially drained, and $0.2 \%$ were diked (Table 1). Overall, $25.7 \%$ of semipermanent basins, $13.5 \%$ of seasonal basins, and $6.8 \%$ of temporary basins were classified as modified. Excavation was the most common modification for seasonal and semipermanent basins, whereas temporary basins were most often modified by partial drainage. Only a small portion $(\leq 7.3 \%)$ of excavated temporary or seasonal wetlands occurred in either the outer plot or outer transect areas (Figure 3). Nearly all excavated temporary $(89 \%)$ and seasonal $(90 \%)$ basins occurred in the inner transect, reflecting the high proportion that would be defined as a roadside ditch. Excavated semipermanent basins were more evenly distributed among the three sample areas; these basins often were dugouts but also included roadside ditches. Partially drained wetlands also were fairly evenly distributed among the three sample areas.

Excavated temporary and seasonal basins occurred at greater densities in the inner transect area than in the outer transect or outer plot area $(P<0.05)$; results were consistent for all 38 plots. No differences were detected in basin densities between outer plot and outer transect areas for any regime-modification type, indicating that these two areas were similar. Therefore, we pooled the outer plot and outer transect areas and refer to this larger area as the non-road area. Only slight differences were suggested for diked semipermanent basins (slightly higher in outer transect area than the outer plot area; $P=0.107$ ) and excavated semipermanent basins (slightly higher in outer transect area; $P=0.119$ ). We then examined differences in

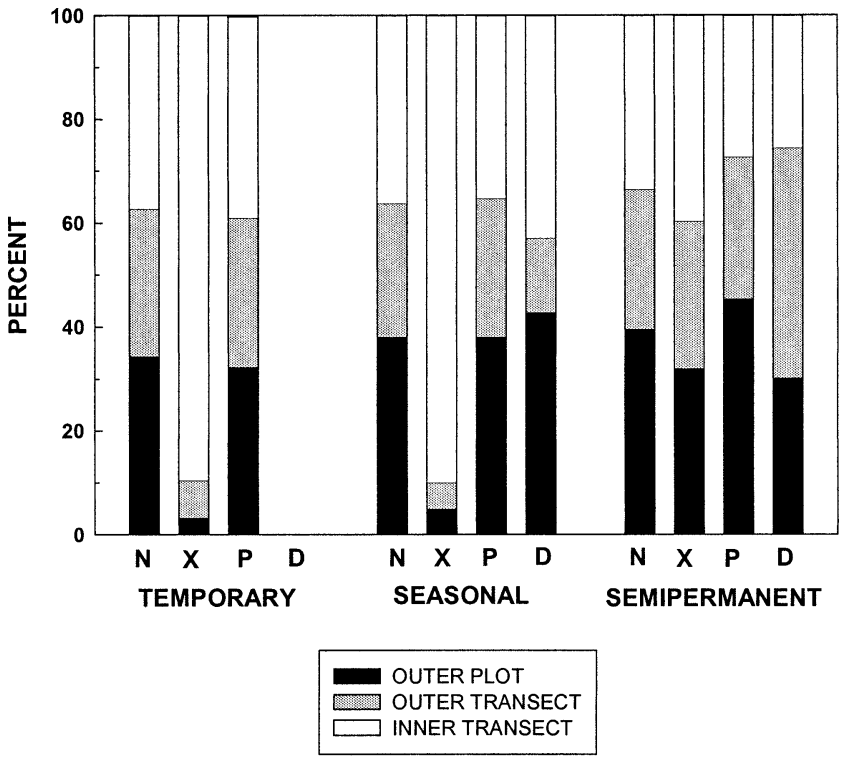

Figure 3. Proportion of unmodified and modified basins occurring in the outer plot, outer transect, and inner transect samples, for thirty-eight $40-\mathrm{km}^{2}$ plots in North Dakota. Basin types: $\mathrm{N}=$ umodified, $\mathrm{X}=$ excavated, $\mathrm{P}=$ partially drained, and $\mathrm{D}=$ diked.

basin densities between the entire plot and 1) inner transect area and 2) non-road area to determine whether the areas were representative of the larger landscape (plot) and also the magnitude of any differences.

Densities of excavated seasonal and temporary basins were greater in the inner transect area than in the plot $(P<0.001)$ (Table 2$)$. These densities averaged $>140 \%$ greater than in the plot and ranged from $88 \%$ to $>300 \%$ greater. Densities of unmodified seasonal basins also were $17 \%$ greater in the inner transect area than in the entire plot $(P<0.020)$. Conversely, the non-road area had fewer excavated temporary and seasonal basins (92 and $86 \%$ of plot density, respectively) and for unmodified seasonal basins (12\% of plot density).

\section{Duck Distribution}

Mallard use of wetland basins varied among waterregime-modifier combinations $\left(F_{4,148}=3.54, P=\right.$ 0.009) (Table 3). Semipermanent basins had more use by mallards when they were partially drained than when they were excavated or unmodified. Use of temporary and seasonal basins did not differ by modification type.

Pintail use of wetland basins also varied among water-regime-modifier combinations $\left(F_{4,148}=2.62, P=\right.$ 0.037) (Table 1). Semipermanent and seasonal basins had more use when they were partially drained than when they were excavated or unmodified. Use of tem- 
Table 2. Bias $(\overline{\mathrm{x}} \pm \mathrm{SE})$ in density of modified and unmodified basins, by water regime, as measured in 400-m-wide roadside transect areas (inner transect area), on thirty-eight $40-\mathrm{km}^{2}$ plots in North Dakota.

\begin{tabular}{|c|c|c|c|c|c|c|c|c|}
\hline \multirow[b]{2}{*}{ Water Regime } & \multirow[b]{2}{*}{ Modification } & \multirow{2}{*}{$\begin{array}{l}\text { No. } \\
\text { Plots }\end{array}$} & \multicolumn{2}{|c|}{ Bias (No./100 ha) ${ }^{1}$} & \multicolumn{4}{|c|}{ Bias as $\%$ of Plot Density } \\
\hline & & & $\overline{\mathrm{x}}$ & SE & $\overline{\mathrm{x}}$ & SE & Min & Max \\
\hline \multirow[t]{4}{*}{ Temporary } & Unmodified & 38 & 0.1099 & 0.1293 & 8.2 & 5.7 & -41.9 & +146.1 \\
\hline & Excavated & 10 & 0.4208 & $0.0689 * *$ & 145.7 & 11.0 & +88.4 & +202.5 \\
\hline & Diked & 1 & - & - & - & - & - & - \\
\hline & Partially drained & 24 & +0.0235 & 0.0346 & -7.2 & 13.0 & -100.0 & +150.4 \\
\hline \multirow[t]{4}{*}{ Seasonal } & Unmodified & 38 & 0.4513 & $0.2109 *$ & 16.6 & 5.5 & -28.2 & +111.9 \\
\hline & Excavated & 30 & 1.3706 & $0.1877 * *$ & 159.6 & 10.9 & +88.0 & +339.3 \\
\hline & Diked & 5 & 0.0135 & 0.0316 & 24.5 & 77.3 & -100.0 & +251.6 \\
\hline & Partially drained & 22 & 0.0250 & 0.0356 & -16.4 & 15.2 & -100.0 & +109.6 \\
\hline \multirow[t]{4}{*}{ Semipermanent } & Unmodified & 38 & -0.0038 & 0.0365 & 1.3 & 9.5 & -100.0 & +200.5 \\
\hline & Excavated & 30 & -0.0189 & 0.0231 & 5.7 & 9.0 & -100.0 & +111.9 \\
\hline & Diked & 15 & -0.0211 & 0.0106 & -37.3 & 25.0 & -100.0 & -194.8 \\
\hline & Partially drained & 8 & -0.0024 & 0.0125 & -21.7 & 23.1 & -100.0 & +35.6 \\
\hline
\end{tabular}

$* P<0.05$

$* * P<0.001$

${ }^{1}$ Bias is the difference in basin density between transect sample areas and plot area. Positive signs indicate higher densities in the transect sample area.

porary basins did not differ by modification type. Use of wetland basins by gadwall, blue-winged teal, and shovelers did not differ among water regimes or modification $(P>0.05)$.

\section{DISCUSSION}

We demonstrated the obvious: roadside strip transects provide a biased measure of densities of excavated seasonal and temporary basins relative to the larger landscape. The importance of these findings lies in the quantification of differences in pond counts determined by roadside transects compared to non-road areas. In those roadside surveys that consider all wetland basins regardless of type or modification, differences or bias in pond counts usually will be quite high (Austin et al. 2000). The magnitude of bias will depend in part on the proportion of temporary and seasonal basins on the landscape and the proportion of these that are roadside ditches. Areas with predominantly seasonal basins will have greater bias in strip samples than areas with semipermanent basins unless the semipermanent basins are large (Johnson and Higgins 1998, Austin et al. 2000). Excluding roadside ditches from pond counts would reduce or eliminate this bias but may have other implications (see below).

Partially-drained semipermanent basins received more use by mallards and pintails than unmodified, excavated, or diked basins. Pintails also used partiallydrained seasonal basins more than unmodified or diked seasonal basins. We speculate that partial drainage of semipermanent basins in our study resulted in these wetlands functioning as a more stable seasonal water regime, which provided invertebrate resources that were attractive and more available to mallards and pintails than in other semipermanent basins. The groundwater contribution associated with many semipermanent wetlands would result in more stable water con-

Table 3. Least squares means (LSM) \pm SE of weighted $\gamma$ (gamma), indicating relative use of basins by mallards and northern pintails on thirty-eight $40-\mathrm{km}^{2}$ plots in North Dakota.

\begin{tabular}{|c|c|c|c|c|c|c|c|}
\hline \multirow[b]{3}{*}{ Species } & \multirow[b]{3}{*}{ Water Regime } & \multicolumn{6}{|c|}{ Modification Type } \\
\hline & & \multicolumn{2}{|c|}{ Partially Drained } & \multicolumn{2}{|c|}{ Excavated } & \multicolumn{2}{|c|}{ Unmodified } \\
\hline & & LSM & SE & LSM & SE & LSM & SE \\
\hline \multirow[t]{3}{*}{ Mallard } & Temporary & $1.916 \mathrm{~A}^{1}$ & 1.351 & $2.180 \mathrm{~A}$ & 1.630 & $2.905 \mathrm{~A}$ & 0.851 \\
\hline & Seasonal & $3.114 \mathrm{~A}$ & 1.351 & $1.554 \mathrm{~A}$ & 0.935 & $2.610 \mathrm{~A}$ & 0.824 \\
\hline & Semipermanent & $11.553 \mathrm{~B}$ & 2.265 & $4.022 \mathrm{~A}$ & 1.016 & $2.737 \mathrm{~A}$ & 0.861 \\
\hline \multirow[t]{3}{*}{ Pintail } & Temporary & $2.081 \mathrm{~A}$ & 1.510 & $1.483 \mathrm{~A}$ & 1.844 & $2.148 \mathrm{~A}$ & 0.896 \\
\hline & Seasonal & $8.351 \mathrm{~B}$ & 1.510 & $0.909 \mathrm{~A}$ & 0.999 & $2.178 \mathrm{~A}$ & 0.861 \\
\hline & Semipermanent & 8.099 B & 2.599 & $1.944 \mathrm{~A}$ & 1.099 & $1.204 \mathrm{~A}$ & 0.908 \\
\hline
\end{tabular}

${ }^{1}$ Least squares means within a water regime (row) having the same letter are not significantly different $(P>0.05)$. 
ditions in a partially-drained semipermanent wetland than in a natural seasonal wetland, particularly in dry years. Shallower water depths due to partial drainage would make invertebrate resources more readily available to dabbling ducks, particularly benthic invertebrates such as Chironomid larvae (Krapu 1974, Swanson et al. 1985). In very wet years, as experienced in 1995, deeper flooding in these wetlands would be prevented by the drain; thus, the basin would be unable to progress into open or regenerating marsh phase (van der Valk and Davis 1978). Similarly, partially-drained seasonal wetlands would be shallower and have a shorter flooding period than natural seasonal wetlands, and thus, they may have a plant and invertebrate communities more similar to those found in temporary wetlands. Such ephemeral wetlands are attractive to pintails (Krapu 1974, Austin and Miller 1995). Impacts of partial drainage to wetland function and value to waterfowl will vary with soils, topographic changes made to the basin, original hydrologic function of the basin (discharge, recharge, or flow-through), and its location in a wetland complex. At the time of our study, unmodified semipermanent basins and some seasonal basins had become so deep from above-average precipitation that they were transforming into the degenerating marsh phase, and emergent vegetation often was deeply flooded, restricting opportunities for foraging. Why blue-winged teal and northern shovelers did not show a similar response as pintails, however, is unclear, as these species also are associated with seasonal wetlands (Stewart and Kantrud 1973).

We did not detect any difference in duck response to water in excavated basins compared to unmodified basins. We had speculated that these excavated basins would receive less use than unmodified basins because the altered hydrology could reduce attractiveness or productivity for foraging and because road disturbances would deter duck use of road-side excavated basins. Stewart and Kantrud (1973) considered roadside ditches and drainage channels as low value habitat for ducks; they found that these basins accounted for $4 \%$ of the basin numbers in the PPR of North Dakota but held only $2 \%$ of ducks. More than 20 years had elapsed since these wetlands had been classified as excavated in the NWI data, and most roadside ditches were probably established during the first half of the 1900 s when the state's population was greatest and most gravel roads were built. Thus, by 1995, these wetlands may have been functioning similarly to unmodified wetlands of comparable water regime. Disturbances to ducks from road traffic may be relatively light because vehicle traffic is relatively infrequent, and any influences of such disturbance probably are not detectable by a broad-scale study such as ours. Specific studies are needed to evaluate the influence of road infrastructure and related disturbance on wetland characteristics, function, and waterfowl use more directly.

Our study was conducted during only one year, which was 1.5 years after the end of a prolonged drought and during a period in which water levels and wetland densities were high relative to long-term conditions (U.S. Fish and Wildlife Service 2001). We relied on wetland classification and modification data from NWI data, which were determined based on moderate water conditions in the late 1970s, rather than field determination in our study. Water regime may have changed (e.g., shifted to a more permanent water regime), and additional modifications may have occurred that we did not detect. In general, however, water-regime classifications and special modifier categories did not seem to have changed substantially from that noted on the NWI maps.

Our results for ducks apply to the PPR of North Dakota during high water conditions. During dry years, ducks may show greater use of excavated or diked wetlands because they would be more likely to hold water under drought conditions (Stewart and Kantrud 1973). A repeat of this study under moderate and dry conditions would be very useful to improve our understanding of the roles modified basins have under various water conditions. Duck responses to modified basins also may differ among regions depending on wetland composition and conditions in the landscape. Stewart and Kantrud (1973) found that a high proportion of breeding ducks in the southwestern slope region of North Dakota were on stock ponds and dugouts; these excavated and diked basins also were used to considerable extent in the Coteau Slope Region.

We found no evidence to indicate that duck numbers determined using standard roadside transects (i.e., 400$\mathrm{m}$ wide) are biased relative to a larger landscape scale $\left(40 \mathrm{~km}^{2}\right)$. First, we found no difference in duck response between excavated and unmodified basins, indicating that duck counts will not be biased by the greater densities of excavated basins within roadside strip transects. Further, we found no evidence that the stronger response to water in the inner transect area by blue-winged teal and northern shovelers noted in Austin et al. (2000) was related to the high densities of excavated basins therein. Rather, ducks probably are responding simply to water regime or wetland densities within that area. The greater use by mallards and pintails of partially-drained semipermanent and seasonal basins also would not likely affect surveys because partially-drained basins were equally distributed in the landscape relative to road rights-of-way. Thus, we believe that duck numbers derived from roadside 
transects are reasonably representative of a larger landscape area.

Pond counts derived from standard roadside transects, and relationships between pond counts (densities) and duck numbers, however, would be biased. The extent of the bias depends on how pond counts are conducted. For example, roadside transect surveys conducted by the North Dakota Game and Fish Department for estimating spring waterfowl populations include all ponds within the transect, regardless of water regime or modification, for the pond count. While the pond counts would be biased relative to a larger area, that measure of water availability accounts for all wetland or water types to which ducks are responding. A different protocol for counting ponds exists for the annual Waterfowl Breeding Population and Habitat Surveys conducted across the PPR by the U.S. Fish and Wildlife Service and Canadian Wildlife Service. Pond counts exclude "roadside or borrow ditches where water is confined entirely to the ditch and small ditches used for local irrigation" (U.S. Fish and Wildlife Service and Canadian Wildlife Service 1987). Bias in wetland densities on roadside transects was due to the presence of excavated seasonal and temporary basins (Austin et al. 2000); therefore, such an exclusion of roadside ditches would result in an unbiased or less biased measure of pond densities in the larger landscape. The most ephemeral wetlands included in annual waterfowl breeding population surveys are considered Type III wetlands (Shaw and Fredine 1956; most closely equivalent to Stewart and Kantrud's [1971] seasonal wetlands); these refer to "hay meadows or basins containing natural aquatics which normally are dry by midsummer but are expected without additional precipitation to retain water for at least three weeks following the observation" (U.S. Fish and Wildlife Service and Canadian Wildlife Service 1987). This exclusion of temporary wetlands would further reduce the measure of wetland density within the sampled area. However, as noted above, ducks seem to be responding to wetland types and water area present in the area surveyed regardless of road rights-of-way or basin modifications. Therefore, correlations between pond counts that exclude ditches or temporary basins and numbers of ducks in them would be incorrect and not reflect the response of ducks to available water.

\section{ACKNOWLEDGMENTS}

Primary funding and support for this study was provided by the U. S. Geological Survey. Partial funding was provided by the U.S. Environmental Protection Agency (EPA), National Health and Environmental Effects Research Laboratory-Western Ecology Division through Interagency Agreement Number (DW
14936583). The manuscript has not been subjected to EPA's peer or administrative review process. L. Cowardin designed the sampling frame and procedures. W. Norling assisted with data collection and entry. S. Magill provided statistical assistance. We thank D. Howerter, C. Johnson, K. Higgins, W. Newton, T. Shaffer, and G. Smith for comments on earlier drafts.

\section{LITERATURE CITED}

Austin, J. E., H. T. Sklebar, G. R. Guntenspergen, and T. K. Buhl 2000. Effects of roadside transect width on waterfowl and wetland estimates. Wetlands 20:660-670.

Austin, J. E., G. R. Guntenspergen, H. T. Sklebar, and T. K. Buhl. 2001. Duck populations as indicators of landscape condition in the Prairie Pothole Region. Environmental Monitoring and Assessment 69:29-47.

Austin, J. E. and M. R. Miller. 1995. Northern pintail (Anas acuta). In A. Poole and F. Gill (eds.) The Birds of North America, No. 163. The Academy of Natural Sciences, Philadelphia, PA, USA, and The American Ornithologists' Union, Washington, DC, USA.

Cowardin, L. M., V. M. Carter, F. C. Golet, and E. T. LaRoe. 1979. Classification of wetlands and deepwater habitats of the United States. U.S. Fish and Wildlife Service, Biological Services Program, Washington, DC, USA. FWS/OBS-79/31.

Cowardin, L. W., D. S. Gilmer, and L. M. Mechlin. 1981. Characteristics of central North Dakota wetlands determined from sample aerial photographs and ground study. Wildlife Society Bulletin 9: 280-288.

Cowardin, L. M., D. H. Johnson, A. M. Frank, and A. T. Klett. 1983. Simulating results of management actions on mallard production. Transactions of the North American Wildlife and Natural Resource Conference 48:257-272.

Cowardin, L. M., D. H. Johnson, T. L. Shaffer, and D. W. Sparling. 1988. Applications of a simulation model to decisions in mallard management. U.S. Fish and Wildlife Service Technical Report 17.

Cowardin, L. M., T. L. Shaffer, and P. M. Arnold. 1995. Evaluations of duck habitat and estimation of duck population sizes with a remote-sensing-based system. National Biological Service, Biological Science Report 2.

Dahl, T. E. 2000. Status and trends of wetlands in the conterminous United States 1986 to 2000. U.S. Department of Interior, Fish and Wildlife Service, Washington, DC, USA.

Dzubin, A. 1969. Assessing breeding populations of ducks by ground counts. Saskatoon Wetlands Seminar. Canadian Wildlife Report Series 6:178-230.

Euliss, N. H., Jr., D. A. Wrubleski, and D. M. Mushet. 1999. Wetlands of the prairie pothole region: invertebrate species composition, ecology, and management. p. 471-514. In D. P. Batzer, R. B. Rader, and S. A. Wissinger (eds.) Invertebrates in Freshwater Wetlands of North America: Ecology and Management. John Wiley and Sons, New York, NY, USA.

Johnson, R. R. and K. F. Higgins. 1997. Wetland Resources of Eastern South Dakota. South Dakota State University, Brookings, SD, USA.

Johnson, R. R. and K. F. Higgins. 1998. Bias in quadrat-derived estimates of number of prairie wetlands. Wetlands 18:329-334.

Kantrud, H. A., G. L. Krapu, and G. L. Swanson. 1989. Prairie basin wetlands of the Dakotas: a community profile. U.S. Fish and Wildlife Service Biological Report 85(7.28).

Krapu, G. L. 1974. Feeding ecology of pintail hens during reproduction. Auk 91:278-290.

Littell, R. C., G. A. Milliken, W. W. Stroup, and R. W. Wolfinger. 1996. SAS system for mixed models. SAS Institute, Inc., Cary, NC, USA.

Lokemoen, J. T. 1973. Waterfowl production on stock-watering ponds in the northern plains. Journal of Range Management 26: 179-184.

Rumble, M. A. and L. D. Flake. 1983. Management considerations 
to enhance use of stock ponds by waterfowl broods. Journal of Range Management 36:691-694.

SAS Institute, Inc. 1997. SAS user's guide, version 6, 5th edition. SAS Institute, Inc., Cary, NC, USA.

Serie, J. R. and L. M. Cowardin. 1990. Use of social indices to predict reproductive success in canvasbacks. Journal of Wildlife Management 54:66-72.

Shaw, S. P. and C. G. Fredine. 1956. Wetlands of the United States. U.S. Fish and Wildlife Service Circular 39.

Stewart, R. E. and H. A. Kantrud. 1971. Classification of natural ponds and lakes in the glaciated prairie region. U.S. Fish and Wildlife Service Resource Publication 92.

Stewart, R. E. and H. A. Kantrud. 1973. Ecological distribution of breeding waterfowl populations in North Dakota. Journal of Wildlife Management 37:39-50.

Svingen, D. and S. H. Anderson. 1998. Waterfowl management on grass-sage stock ponds. Wetlands 18:84-89.

Swanson, G. A., M. I. Meyer, and V. A. Adomaitis. 1985. Foods consumed by breeding mallards on wetlands in south-central North Dakota. Journal of Wildlife Management 49:197-203.

U.S. Fish and Wildlife Service. 2001. Waterfowl population status, 2001. U.S. Department of Interior, Fish and Wildlife Service, Washington, DC, USA.

U.S. Fish and Wildlife Service and Canadian Wildlife Service. 1987. Standard operating procedures for aerial waterfowl breeding ground population and habitat surveys in North America. Office of Migratory Bird Management, Laurel, MD, USA.

van der Valk, A. G. and C. B. Davis. 1978. The role of seed banks in the vegetation dynamics of prairie glacial marshes. Ecology 59: 322-335.

Zimmer, K. D., M. A. Hanson, and M. G. Butler. 2000. Factors influencing invertebrate communities in prairie wetlands: a multivariate approach. Canadian Journal of Fisheries and Aquatic Sciences 57:76-85.

Manuscript received 5 August 2002; revisions received 12 November 2002; accepted 2 December 2002. 